\title{
Group Member Prototypicality and Intergroup Negotiation: How One's Standing in the Group Affects Negotiation Behaviour
}

\section{Gerben A. Van Kleef, Wolfgang Steinel, Daan van Knippenberg, Michael A. Hogg and Alicia Svensson}

\begin{tabular}{|l|l|}
\hline \multicolumn{2}{|l|}{ ERIM REPORT SERIES RESEARCH IN MANAGEMENT } \\
\hline ERIM Report Series reference number & ERS-2006-070-ORG \\
\hline Publication & August 2006 \\
\hline Number of pages & 46 \\
\hline Persistent paper URL & \\
\hline Email address corresponding author & g.a.vankleef@uva.nl \\
\hline Address & Erasmus Research Institute of Management (ERIM) \\
& RSM Erasmus University / Erasmus School of Economics \\
& Erasmus Universiteit Rotterdam \\
& P.O.Box 1738 \\
& 3000 DR Rotterdam, The Netherlands \\
& Phone: + 31 10 408 1182 \\
& Fax: + 31 104089640 \\
& Email: info@erim.eur.nl \\
& Internet: www.erim.eur.nl \\
\hline
\end{tabular}

Bibliographic data and classifications of all the ERIM reports are also available on the ERIM website: www.erim.eur.nl 


\section{ERASMUS RESEARCH INSTITUTE OF MANAGEMENT}

\section{REPORT SERIES}

\section{RESEARCH IN MANAGEMENT}

\begin{tabular}{|c|c|}
\hline \multicolumn{2}{|c|}{ ABSTRACT AND KEYWORDS } \\
\hline Abstract & $\begin{array}{l}\text { How does a representative's position in the group influence behaviour in intergroup negotiation? } \\
\text { Applying insights from the social identity approach (specifically self-categorization theory), the } \\
\text { effects of group member prototypicality, accountability, and group attractiveness on } \\
\text { competitiveness in intergroup bargaining were examined. As representatives of their group, } \\
\text { participants engaged in a computer-mediated negotiation with a simulated outgroup opponent. In } \\
\text { Exp. } 1(\mathrm{~N}=114) \text {, representatives with a peripheral status in the group sent more competitive and } \\
\text { fewer cooperative messages to the opponent than did prototypical representatives, but only } \\
\text { under accountability. Exp. } 2(\mathrm{~N}=110) \text { replicated this finding, and showed that, under } \\
\text { accountability, peripherals also made higher demands than did prototypicals, but only when } \\
\text { group membership was perceived as attractive. Results are discussed in relation to impression } \\
\text { management and strategic behaviour. }\end{array}$ \\
\hline Free Keywords & $\begin{array}{l}\text { Group Member Prototypicality, Intergroup Negotiation, Negotiation Behaviour, } \\
\text { Representatives Bahaviour }\end{array}$ \\
\hline Availability & $\begin{array}{l}\text { The ERIM Report Series is distributed through the following platforms: } \\
\text { Academic Repository at Erasmus University (DEAR), DEAR ERIM Series Portal } \\
\text { Social Science Research Network (SSRN), SSRN ERIM Series Webpage } \\
\text { Research Papers in Economics (REPEC), REPEC ERIM Series Webpage }\end{array}$ \\
\hline Classifications & $\begin{array}{l}\text { The electronic versions of the papers in the ERIM report Series contain bibliographic metadata } \\
\text { by the following classification systems: } \\
\text { Library of Congress Classification, (LCC) } \underline{\text { LCC Webpage }} \\
\text { Journal of Economic Literature, (JEL), JEL Webpage } \\
\text { ACM Computing Classification System CCS Webpage } \\
\text { Inspec Classification scheme (ICS), ICS Webpage }\end{array}$ \\
\hline
\end{tabular}


Running Head: SOCIAL IDENTITY AND INTERGROUP NEGOTIATION

Group Member Prototypicality and Intergroup Negotiation:

How One's Standing in the Group Affects Negotiation Behaviour

Gerben A. Van Kleef and Wolfgang Steinel

University of Amsterdam, The Netherlands

\author{
Daan van Knippenberg \\ Erasmus University Rotterdam, The Netherlands
}

Michael A. Hogg and Alicia Svensson

University of Queensland, Australia

British Journal of Social Psychology, forthcoming

This research was supported by a grant from the Australian Research Council awarded to Michael Hogg. We thank Astrid Homan and Bernard Nijstad for their valuable comments on a previous version of this article.

Wolfgang Steinel is now at Leiden University, Leiden, The Netherlands.

Correspondence concerning this article should be addressed to Gerben A. Van Kleef, University of Amsterdam, Department of Social Psychology, Roetersstraat 15, 1018 WB Amsterdam, The Netherlands. E-mail: g.a.vankleef@uva.nl. Tel. +31 20525 6984; Fax +31 206391896. 


\begin{abstract}
How does a representative's position in the group influence behaviour in intergroup negotiation? Applying insights from the social identity approach (specifically selfcategorization theory), the effects of group member prototypicality, accountability, and group attractiveness on competitiveness in intergroup bargaining were examined. As representatives of their group, participants engaged in a computer-mediated negotiation with a simulated outgroup opponent. In Exp. $1(N=114)$, representatives with a peripheral status in the group sent more competitive and fewer cooperative messages to the opponent than did prototypical representatives, but only under accountability. Exp. $2(N=110)$ replicated this finding, and showed that, under accountability, peripherals also made higher demands than did prototypicals, but only when group membership was perceived as attractive. Results are discussed in relation to impression management and strategic behaviour.
\end{abstract}


Group Member Prototypicality and Intergroup Negotiation:

How One's Standing in the Group Affects Negotiation Behaviour

Social interactions can produce conflict at all levels of society. One of the most common and constructive ways of resolving such conflicts is through negotiation, which can be defined as a discussion between two or more parties aimed at resolving a perceived divergence of interests (Pruitt \& Carnevale, 1993). Many negotiations are conducted by representatives, that is, negotiators who represent the interests of a group. Although such negotiations have a tremendous impact on society, the factors that influence the behaviour of representatives in intergroup negotiations are poorly understood. What factors determine the competitiveness of their demands and communications? When do negotiators yield and when do they stand firm? To answer these questions, the present research applies principles from the social identity approach (e.g., Hogg, 2003; Hogg \& Abrams, 1988), specifically from self-categorization theory (Turner, 1985; Turner, Hogg, Oakes, Reicher, \& Wetherell, 1987), to intergroup negotiation, starting from the assumption that the representative's standing within the group plays a crucial role in determining his or her negotiation behaviour.

Although influential negotiation theorists have traditionally made no distinction between interpersonal and intergroup negotiation, these types of negotiation differ in important respects (Couch, 1986; Pruitt \& Carnevale, 1993; Putnam \& Poole, 1987). An obvious yet important characteristic of intergroup negotiation is that it is typically not feasible for all those concerned to be present at the bargaining table. Therefore, intergroup negotiations are usually conducted by representatives (Adams, 1976; Rubin \& Sander, 1988; Walton \& McKersie, 1965). This notion introduces an additional set of features that do not apply in interpersonal negotiation. For example, negotiators who negotiate on behalf of a group tend to be strongly motivated to make a positive impression and avoid making a negative impression on their constituents (Adelberg \& Batson, 1978; Gruder \& Rosen, 1971; 
Wall, 1975, 1991), which is often reflected in a reduced willingness to make concessions (Benton, 1972; Druckman, Solomon, \& Zechmeister, 1972).

In a related vein, research indicates that people take a more competitive stance in intergroup than in interpersonal negotiations (Insko, Schopler, Hoyle, Dardis, \& Graetz, 1990; Komorita \& Lapworth, 1982; Kramer, 1991b; Lindskold, McElwain, \& Wayner, 1977; Schopler, Insko, Graetz, Drigotas, \& Smith, 1991; Stephenson, 1981). Similarly, negotiators judge coercion to be more effective than conciliation when dealing with an outgroup rather than an ingroup (Brewer \& Kramer, 1986; Kramer, 1991a; Rothbart \& Hallmark, 1988), and they tend to believe that their constituents favour a tough approach as well (Benton \& Druckman, 1974; Druckman, 1994). Therefore, negotiators' tendency to take a competitive stance in intergroup negotiation is increased when they are accountable to their groups (BenYoav \& Pruitt, 1984; Carnevale, Pruitt, \& Britton, 1979; Carnevale, Pruitt, \& Seilheimer, 1981; Gelfand \& Realo, 1999; Gruder, 1971; Klimoski, 1972; Klimoski \& Ash, 1974).

This research has increased understanding of how representatives' behaviour is influenced by the fact that they are part of a larger collective that may hold them accountable for the negotiation process and outcome. However, it is relatively silent with respect to the question of how the representative's relation to those constituents, that is, his or her position within the group, affects his or her behaviour. And yet a negotiator's position within the group may play a critical role. Research has found that accountable representatives take longer to reach an agreement, but only when they are attracted to their group (Breaugh \& Klimoski, 1977; Klimoski, 1972). Other research suggests that representatives who enjoy high status within their group may be less tied to their constituents' views and have more leeway to make concessions than those with low status (Hermann \& Kogan, 1968; Kogan, Lamm, \& Trommsdorff, 1972). Finally, negotiators who feel distrusted by their constituents tend to make tougher demands and reach fewer agreements than those who feel trusted (Frey 
\& Adams, 1972; Haccoun \& Klimoski, 1975; Klimoski \& Ash, 1974; Wall, 1975).

Prototypicality and Intergroup Negotiation

Previous research suggests that negotiators behave more competitively in intergroup negotiations because they wish to make a favorable impression on their constituents.

However, this research has ignored the question of why negotiators are motivated to make a favorable impression. Adopting a social identity perspective on intergroup negotiation, we propose that negotiators may be strategically motivated to make a favorable impression on their group members because they believe that this will lead to greater acceptance by the other group members. People derive an important aspect of their self-concept from their membership of certain groups (Tajfel \& Turner, 1986; Turner, 1985; Turner et al., 1987), and they have a strong desire to feel included in, and accepted by, those groups (Baumeister \& Leary, 1995). The extent to which people will be concerned about being accepted by their group members is likely to depend, among other things, on their position within the group-those who are at the periphery of the group have more reason to be concerned about being accepted as a group member than those who are at the core of the group (e.g., Noel, Wann, \& Branscombe, 1995; van Knippenberg, van Knippenberg, \& van Dijk, 2000).

This distinction between peripheral and core group members is closely reflected in the concept of group member prototypicality, which is central to self-categorization theory (Turner, 1985; Turner et al., 1987; also see Hogg, 2003). Group members vary in the extent to which they are prototypical of the group, that is, representative of what the members of the group have in common and what differentiates the group from other groups. Some group members possess characteristics that are more prototypical of the group, and therefore can be considered better examples of the group than others (Hogg, 1993, 2005; Hogg, Cooper-Shaw, \& Holzworth, 1993; Noel et al., 1995; Turner et al., 1987). Group members who strongly match group prototypes can be referred to as prototypical group members. Individuals who 
are less prototypical examples of their group can be referred to as peripheral group members (e.g., Hogg, 2005; Noel et al., 1995).

A considerable body of research has documented that prototypical group members enjoy more standing within the group than peripheral group members (Fielding \& Hogg, 1997; Hogg, 2001; Hains, Hogg, \& Duck, 1997; Hogg, Hains, \& Mason, 1998; Hogg \& van Knippenberg, 2003; Platow \& van Knippenberg, 2001; van Knippenberg et al., 2000; van Knippenberg, Lossie, \& Wilke, 1994). Group members who find themselves in a peripheral position in the group may thus be motivated to assert their group belongingness, demonstrating that, despite their apparent position, they are true (i.e., prototypical) members of the group (Noel et al., 1995; Schmitt \& Branscombe, 2001; see also Ellemers, Spears, \& Doosje, 2002). One way in which peripheral group members may improve their position within the group is by presenting themselves as holding especially favourable attitudes toward the ingroup or unfavourable attitudes toward the outgroup (Ellemers et al., 2002; Jones \& Pittman, 1982) or by stressing characteristics that they share with the ingroup prototype (Schmitt \& Branscombe, 2001). However, such strategies are only useful when the focal group member's attitudes toward the ingroup and/or the outgroup become known to the other group members. Consistent with this idea, Noel et al. (1995) found that peripheral group members expressed more negative judgments and advocated more coercive behaviour against the outgroup than did prototypical members, but only under public (not private) conditions. In contrast, prototypical group members' judgments were not influenced by public-private differences.

\section{Prototypicality and Strategic Behaviour}

The above discussion suggests that peripheral group members may be more strategic and sensitive to social context than prototypical group members. Indeed, a growing body of research indicates that peripheral group members' behaviour is fueled by strategic 
considerations. For example, in the aforementioned study by Noel et al. (1995), peripherals displayed high levels of ingroup favouring and outgroup derogating behaviour only when this behaviour was strategically advantageous to them in terms of providing an opportunity to prove their loyalty to the group (i.e., under public conditions). Also suggestive of strategic motives, Jetten, Branscombe, Spears, and McKimmie (2003) found that peripheral group members who identified weakly with the group were less loyal when they anticipated future rejection by the group than when they anticipated future acceptance, suggesting that peripherals are only motivated to behave in ways that are favourable to the group when doing so is likely to result in some kind of strategic advantage (e.g., increased acceptance by the group). Compatible findings were reported by Barreto and Ellemers (2000), who observed that high identifiers displayed pro-group behaviour regardless of whether they were accountable to their group members, whereas low identifiers displayed pro-group behaviour when they were accountable and individualistic behaviour when they were anonymous.

Jetten, Hornsey, and Adarves-Yorno (in press) extended these findings to the domain of conformity, examining how individuals strategically tailor self-reports of conformity as a function of their status within the group. Operationalising prototypicality in terms of seniority, they found support for strategic impression management on the part of junior (i.e., peripheral) group members. Across different samples they found that people who felt more junior were more willing than those who felt senior to admit conformity when they were addressing an ingroup as opposed to an outgroup audience and when they believed their responses would be made public rather than remain private. Finally, in a recent series of studies Jetten, Hornsey, Spears, Haslam, and Cowell (2005) found that peripheral group members were more likely to express loyalty when they felt monitored, when identity threat was low, when the audience was high status, and when there was little risk of alienating other ingroup members. On the basis of these findings Jetten et al. concluded that peripheral group 
members are more sensitive to social context than are prototypical group members. Furthermore, they concluded that peripherals are more likely than prototypicals to make a strategic cost-benefit analysis to inform their behaviour. When the benefits of keeping up the appearance of being a good group member exceed the costs, they argue, peripherals will display pro-group behaviour. When the costs outweigh the benefits, however, pro-group behaviour is much less likely.

In sum, then, a growing body of research points to the strategic nature of peripherals' group-related behaviour. It appears that peripherals are more likely to engage in groupserving behaviour to the extent that such behaviour can be expected to have positive consequences for them in the future (e.g., greater acceptance by other group members). What kind of behaviour they will display to prove their groupy credentials is likely to depend on the (presumed) group norm. In many instances peripheral group members can be expected to try to prove their loyalty to the group by favouring the ingroup and/or derogating the outgroup (Noel et al., 1995). Peripheral group representatives involved in intergroup negotiation can be expected to follow an analogous strategy. Given that representatives in intergroup negotiation typically assume that their constituents favour a tough and competitive approach (Benton \& Druckman, 1974; Druckman, 1994), peripheral group representatives can be predicted to take a competitive stance vis-à-vis the outgroup to the extent that they believe this will be strategically advantageous to them in terms of proving their loyalty to the group.

\section{The Present Research}

Despite the pervasiveness of representative negotiation as a conflict management strategy and means of conducting social and economic exchange, very little is know about the factors that determine the behaviour of representatives in intergroup negotiation. We argue that one of the factors that may be of paramount importance in this respect is the 
representative's position in the group (i.e., his or her prototypicality). A prototypical ingroup status may be derived from a number of factors, such as (expectations regarding) acceptance by the other group members (e.g., Jetten et al., 2003), how long one has been a member of the group (c.f. Moreland, 1985; Moreland \& Levine, 1989), or how well one exemplifies the group (e.g., Jetten, Branscombe, \& Spears, 2002; Jetten, Spears, \& Manstead, 1997; Noel et al., 1995). In the present research we focus on the latter type of prototypicality, which rests on the idea that some group members are "better" examples of the ingroup than others because they more closely match the group prototype (Hogg, 2005; Turner, 1985; Turner et al., 1987). In the following we report two experiments that investigated the role of representative prototypicality in intergroup negotiation.

The research reviewed above suggests that representatives with a peripheral status within the group should be especially likely to engage in strategic behaviours aimed at increasing acceptance by the other group members. By contrast, prototypical representatives should be less motivated to engage in such strategic behaviours, because their position within the group is already secure. This difference between prototypical and peripheral representatives should only obtain in situations where the representative's behaviour can be monitored by the other group members. If the representative's behaviour remains unknown to the other group members, strategic self-presentation is no longer possible, and hence no effects should be anticipated.

Based on this line of reasoning, we predicted that peripheral group representatives would display tougher negotiation behaviour vis-à-vis the outgroup than would prototypical representatives, but only under process accountability, that is, if their behaviour can be monitored by their group. This prediction was tested in two experiments, using a computermediated negotiation task. Prior to the negotiation, participants received bogus feedback on a personality test that supposedly divided the participants into two groups, and made them 
either prototypical or peripheral members of their group (see Noel et al., 1995). Participants were then selected to represent their group in negotiation with a representative of the other group, whose behaviour was in reality simulated by the computer (see De Dreu \& Van Kleef, 2004; Hilty \& Carnevale, 1993; Van Kleef, De Dreu, \& Manstead, 2004a, b).

As in prior research, we focused on the two classes of dependent variables that together capture the bulk of negotiation behaviours, namely verbal communications and demands (Thompson \& Hrebec, 1996). Examples of verbal communications include threats, positional commitments, verbalised intentions, and meta-communications regarding the mutually optimal negotiation strategy. On the other hand, there is a class of behaviours related to the actual division of resources, which includes placing demands, making offers, and making concessions. We cover both classes of behaviours by focusing on cooperative and competitive communications on the one hand, and actual demands on the other.

\section{Experiment 1}

The purpose of Experiment 1 was to examine the interactive effects of group member prototypicality and process accountability on the representative's behaviour in intergroup negotiation. Based on the research discussed above, it can be predicted that peripheral group members will show tougher negotiation behaviour than prototypical group members, but only when they are accountable to their constituents. Thus, we hypothesised that, under conditions of accountability, peripheral group representatives would send fewer cooperative messages (Hypothesis 1a), send more competitive messages (Hypothesis $1 \mathrm{~b}$ ), and report more competitive intentions (Hypothesis 1c) than prototypical representatives. We further hypothesised that peripheral group members would place higher demands than would prototypical group representatives, but again only under conditions of accountability (Hypothesis 2). No differences were anticipated in the non-accountable conditions. 


\section{Method}

\section{Participants and Experimental Design}

A total of 114 undergraduate students (45 males and 69 females, average age $M=$ 18.86 years, $S D=1.73$ ) at the University of Queensland were randomly assigned to the conditions of a 2 (prototypical vs. peripheral) x 2 (accountable vs. non-accountable) betweenparticipants design.

\section{Procedure}

For each session, between six and eight participants were welcomed to the laboratory. They were told that the experiment had two parts, and that they would be working in groups for both parts. During the first part they would be using the computer network to complete tasks and communicate with their fellow group members, and for the second they would join their group members to work together face-to-face.

As a cover story, we told participants that the purpose of the experiment was to investigate the effect of personality on group decision making, and that they would be divided into two groups on the basis of a relevant personality dimension. To substantiate this story, participants completed a "personality questionnaire" containing items such as "I feel uncomfortable when someone's meaning or intention is unclear to me" and "When trying to solve a problem I often see so many possible options that it's confusing."

Upon completion of the questionnaire, participants were asked to imagine that they worked for an advertising agency that had to create an advertising campaign (i.e., promotional posters) for three new cars, called Amaro, Bailo, and Cogo. They were instructed that each group would create three posters, which would be awarded a certain number of points, and that the groups would be competing against each other for a reward. Participants learned that randomly selected representatives of the two groups would negotiate the reward system for the posters, determining how many points each group would get for 
each poster. It was stressed that it was important to obtain as many points as possible, and that the members of the group that obtained most points would win a voucher for a free lunch.

Manipulation of prototypicality. We used a manipulation of prototypicality that has been successfully employed in prior research (De Cremer, 2002; Noel et al., 1995), providing participants with bogus feedback on the "personality questionnaire." Participants were told that the questionnaire assessed the so-called "O-type/P-type personality." They read that Otype and P-type persons differ in a number of respects, one of which being that they tend to think in different ways and come up with different solutions to problems. They learned that their responses on the personality questionnaire would not only reveal whether they were an O-type or a P-type person, but also how characteristic they were of the O-group or the Pgroup. They read that the computer would characterise each participant as either a typical, a moderate, or a peripheral group member, indicating how well they fit into their group. Participants were then shown a graphical representation of the "O/P continuum" (see Figure 1). In the prototypical group member conditions, their participant number was plotted in the "typical P-type" box of Figure 1. In the peripheral group member conditions, it was plotted in the "peripheral P-type" box. Three other participant numbers were also plotted on the graph, so that in each condition participants were part of a group that had three prototypical members, and one peripheral member. Thus, when the participant was classified as peripheral, the three other group members were all classified as prototypical. When the participant was classified as prototypical, two other group members were classified as prototypical and one as peripheral. ${ }^{1}$

Participants in the prototypical group member conditions then received the following information (adapted from Noel et al., 1995): "Your test score is 63. As you can see, this score places you at the core of the type-P category. You are a typical P-type. This means that 
had you responded somewhat differently to one or two of the questionnaire items, you would still have been classified as a type-P person. Not only do you have more in common with other type-P persons than with type-O persons, you are actually a near perfect example of a type-P person." They further read: "Because you are a typical P-person, it is nicer for you to be in the P-group than in the O-group." Participants in the peripheral group member conditions read: "Your test score is 43. As you can see, this score places you just inside the type-P category. You are a peripheral P-type. This means that had you responded somewhat differently to one or two of the questionnaire items, you would not have been classified as a type-P person. Although you have more in common with other type-P persons than with type-O persons, you are not very characteristic of the type-P group." They further read: "Although you are a peripheral P-person, it is still nicer for you to be in the P-group than in the O-group." This latter sentence was added to make sure that peripheral participants, too, would still feel they belonged more to the P-group (ingroup) than to the O-group (outgroup).

Manipulation of accountability. Participants were instructed that one representative of each group would negotiate, and that he or she would join the group after the negotiation. In the accountability conditions we added that while the representatives were negotiating, the other group members would observe the negotiation via their computer screens, and that the representative would have the opportunity to explain his or her behaviour to the other group members afterwards. In the non-accountability conditions we added that during the negotiation the other group members would fill out a number of questionnaires. The manipulations were followed by a brief simulated chat session to familiarise participants with the computer-mediated interaction and to enhance their sense of groupiness. During the chat session, participants were allowed to send a brief message to their group members, and they received some messages from the other group members referring to the upcoming negotiation and to the lunch prize. 
Selection of the representatives. After the manipulations, the computer ostensibly selected the representatives of the two groups at random. All participants learned that they had been selected as the representative of the P-group. Subsequently, participants were introduced to the negotiation task detailed below.

Negotiation task. The negotiation task was adapted from one used by Van Kleef et al. (2004a, b; see also De Dreu \& Van Kleef, 2004; De Dreu \& Van Lange, 1995; Hilty \& Carnevale, 1993), which captures the main characteristics of real-life negotiation (i.e., multiple issues differing in utility to the negotiator, information about one's own payoffs only, and the typical offer-counteroffer sequence). Participants were presented with a payoff chart (see Table 1) that showed them which outcomes were most favourable to their group, and they were told that their objective was to earn as many points as possible for their group. As can be seen in Table 1, level 9 on the Amaro campaign yielded 0 points and level 1 yielded 400 points (i.e., increments of 50 points per level). For the Bailo campaign, level 9 yielded 0 points, and level 1 yielded 120 points (i.e., increments of 15 points per level). Finally, for the Cogo campaign, level 9 yielded 0 points, and level 1 yielded 240 points (i.e., increments of 30 points per level). Participants read, "You can see that the best deal for your group is $1-1-1$, for a total outcome of 760 points $(400+120+240)$." The corresponding payoff table for the O-group was not displayed, and participants were told only that it differed from their own.

Participants were then invited to make a first offer, and were instructed that the negotiation would continue until an agreement was reached or until time ran out. Over the negotiation rounds the buyer proposed the following levels of agreement (for Amaro - Bailo Cogo): 8-7-8 (round 1), 8-7-7 (round 2), 8-6-7 (round 3), 7-6-7 (round 4), 7-6-6 (round 5), and 6-6-6 (round 6). Past research has shown that this preprogrammed strategy has face validity and is considered intermediate in cooperativeness and competitiveness (De Dreu \& 
Van Lange, 1995). A demand by the participant was accepted if it equaled or exceeded the offer the computer was about to make in the next round. If no agreement was reached after the sixth round, the negotiation was interrupted because up to this point few participants suspect that they are playing against a computer, whereas after the sixth round such suspicion tends to develop (De Dreu \& Van Lange, 1995; Van Kleef et al., 2004a, b).

In each negotiation round participants were presented with a list of seven cooperative and seven competitive messages, and were given the opportunity to select a message from this list to send to the representative of the O-group. Participants could also choose not to send a message. They received no message from the opponent. The messages were adapted from Hilty and Carnevale (1993) and De Dreu (1995), who have shown that messages intended to be cooperative are indeed viewed as cooperative, and that messages intended to be competitive are rated as competitive. Examples of cooperative messages are "Let's try to consider both of our needs and interests" or "I hope that this offer is good for you." Examples of competitive messages are "Improve your offer if you want an agreement" or "This is as far as I will go, take it or leave it."

Dependent measures. Participants' demands in each of the six rounds were transformed into an index revealing the negotiator's total level of demand for that round (i.e., the sum of the number of points asked for each campaign; see Table 1). Levels of demand in the six rounds were in turn combined into an index of the negotiator's average demands (see De Dreu, Carnevale, Emans, \& Van De Vliert, 1994). Furthermore, the participants' cooperative and competitive messages were recorded, as well as the self-rated competitiveness of these messages ("How did you intend this message?"; 1 = very cooperative, 9 = very competitive). After the negotiation, participants were asked "How central to the P-group do you feel you are?" (manipulation check of prototypicality; 1 = not very central, 9 = very central), and "Were your group members watching you during the 
negotiation?" (manipulation check of accountability; 1 = definitely not, 9 = definitely).

\section{Results}

\section{Treatment of the Data}

Data were analyzed by analysis of variance, using the complete 2 (prototypical vs. peripheral) x 2 (accountable vs. non-accountable) design. One participant reached agreement in round 5, and had to be excluded from further analyses due to missing values in round 6. Because the number of rounds was limited, the numbers of competitive messages and cooperative messages sent were in principal dependent (i.e., sending more of the one type leaves less opportunity to send messages of the other type), and results for these two measures should not be regarded as independent observations. For illustrative purposes, however, and because the correlation between the number of cooperative and competitive messages suggested less than complete dependence $(r=-.42, p<.001)$, we report results for both cooperative and competitive messages in a repeated-measures design.

\section{Manipulation Checks}

ANOVA revealed a significant main effect of prototypicality on the prototypicality check, $F(1,109)=18.71, p<.001, \eta^{2}=.14$. Prototypical members indeed felt more prototypical of their group than did peripheral members $(M=6.33, S D=1.77$ vs. $M=4.87$, $S D=1.85$ ). There was no significant effect of accountability, and no interaction (both $F \mathrm{~s}<1$, $n s)$. ANOVA also revealed a significant main effect of accountability on the accountability check, $F(1,109)=21.17, p<.001, \eta^{2}=.16$--accountable negotiators felt more observed by their fellow group members than did non-accountable negotiators $(M=6.02, S D=2.36$ vs. $M$ $=4.24, S D=1.74)$. There were no other significant effects $(F s<1, n s)$. Thus, it can be concluded that the manipulations of prototypicality and accountability were successful. 


\section{Messages}

The numbers of cooperative and competitive messages were submitted to a 2 (prototypical vs. peripheral) x 2 (accountable vs. non-accountable) x 2 (cooperative vs. competitive message) ANOVA with repeated measures on the third factor. This analysis yielded a significant three-way interaction between prototypicality, accountability and message type, indicating that the relative amount of cooperative and competitive messages sent was influenced by prototypicality and accountability, $F(1,109)=9.30, p=.003, \eta^{2}=$ .08. Below we report follow-up analyses that were conducted to examine the specific patterns of cooperative and competitive messages across experimental conditions.

Number of cooperative messages. ANOVA revealed a significant interaction between prototypicality and accountability on the number of cooperative messages sent, $F(1,109)=$ 6.33, $p=.013, \eta^{2}=.06$ (means and standard deviations are presented in Table 2). Consistent with Hypothesis 1a, simple-effects analysis revealed that, under accountability, peripheral group members sent significantly fewer cooperative messages than did prototypical group members, $F(1,109)=5.65, p=.017, \eta^{2}=.10$. In the non-accountability conditions, no significant difference was found, $F(1,109)=1.43, p=.23$.

Number of competitive messages. A compatible pattern of results was obtained for the number of competitive messages sent. Consistent with Hypothesis 1b, we found a significant interaction between prototypicality and accountability, $F(1,109)=6.54, p=.013, \eta^{2}=.06$ (see Table 2 for means and standard deviations). In line with the results pertaining to cooperative messages, simple-effects analysis showed that, when held accountable, peripheral group members sent more competitive messages to the opponent than did prototypical group members, $F(1,109)=9.69, p=.004, \eta^{2}=.14$. Again, no difference was found in the non-accountability conditions, $F(1,109)<1$, ns.

Self-reported competitiveness. Results pertaining to self-reported competitiveness 
were fully consistent with the results described above. In line with Hypothesis 1c, ANOVA yielded a significant interaction between prototypicality and accountability, $F(1,109)=7.57$, $p=.007, \eta^{2}=.07$ (see Table 2). Under accountability, peripheral representatives reported more competitive intentions than did prototypical representatives, $F(1,109)=7.71, p=.006$, $\eta^{2}=.13$, whereas no significant difference was found in the non-accountability conditions, $F(1,109)=1.26, p=.26$.

\section{Demands}

Contrary to our predictions, we found no significant effects of prototypicality and accountability on participants' demands (524 $<$ Ms $<557$; $80<S D s<89$; main effect accountability: $F<1$, $n s$; main effect prototypicality: $F=2.24, p=.14$; accountability $\mathrm{x}$ prototypicality: $F<1, n s)$. Thus, no support was found for Hypothesis 2 .

\section{Discussion}

It was predicted that a representative's prototypicality would influence his or her behaviour in an intergroup negotiation. More specifically, we argued that representatives occupying a peripheral position within the ingroup should be especially likely to display strategic behaviours aimed at proving their loyalty to the group (Branscombe, Wann, Noel, \& Coleman, 1993; Jetten et al., 2003, in press; Noel et al., 1995). Consistent with these predictions, and reflecting the typical belief among representatives that their constituents favour a tough negotiation approach (Benton \& Druckman, 1974; Druckman, 1994), we found that peripheral representatives sent fewer cooperative messages, sent more competitive messages, and reported more competitive intentions than did prototypical representatives, but only under process accountability. However, such competitiveness was not observed at the level of participants' demands.

These findings may be taken to suggest that sending competitive messages and making competitive demands require different levels of motivation to be accepted by the 
group. Sending competitive messages is a relatively safe yet efficient way of conveying a tough impression to one's constituents without risking the negative consequences (e.g., an unprofitable impasse) of making overly intransigent demands (Wall, 1991). It could be, therefore, that in order for peripheral representatives to take the risk of actually engaging in competitive behaviour (i.e., making tough demands), as opposed to merely communicating competitive intentions, they must be more strongly motivated to gain the acceptance of the group (i.e., the threshold for making competitive demands may be higher). This reasoning is in line with Jetten et al.'s (2005) argument that peripheral group members are more sensitive to what the social context affords in determining the utility and costs of expressing group loyalty than are prototypical group members.

The proposition that peripheral group members are motivated to display selfpresentational outgroup derogation to enhance their position within their group rests on the assumption that membership in the group is desirable (Noel et al., 1995; cf. Schmitt \& Branscombe, 2001). Accordingly, peripheral members should engage in behaviours that serve to assert their group belongingness to the extent that group membership is attractive to them. Translating this notion to the present research, we predict that the attractiveness of the group will, at least in part, determine to what extent accountable representatives with a peripheral position are motivated to gain the acceptance and approval of their constituents. As a result, the more attractive the group membership, the more peripheral representatives can be expected to try to gain the acceptance of their group, which should be manifested in higher demands. This prediction was tested in Experiment 2.

\section{Experiment 2}

The objective of Experiment 2 was twofold. First, we aimed to replicate the findings obtained in Experiment 1 for accountable negotiators. Because no effects should be anticipated in the non-accountability conditions, all participants were presented with the high 
accountability instructions. Given that all participants were made accountable, we predicted that peripheral group members would send fewer cooperative messages, send more competitive messages, and report more competitive intentions than prototypical representatives (cf. Hypotheses 1a, 1b, and 1c, Experiment 1). Second, we wanted to test the group attractiveness explanation for the absence of an effect on demands in Experiment 1 . To test this explanation, we manipulated group attractiveness, and predicted that peripheral representatives would make tougher demands than prototypical representatives when the group was attractive, but not when the group was unattractive (Hypothesis 3). Note that we thus predict a main effect of prototypicality on number of cooperative and competitive messages and intentions, and an interaction between prototypicality and group attractiveness on demands. Given that in the accountability condition of Experiment 1 the number of cooperative and competitive messages was already significantly influenced by prototypicality (i.e., in the absence of information that made the group attractive), we did not expect this effect to be moderated by group attractiveness. However, because we did not find an effect of prototypicality on demands in the accountability conditions in Experiment 1, we expected that the effect of prototypicality on demands would be moderated by group attractiveness, such that we should find an effect of prototypicality in the high-attractiveness condition but not in the low-attractiveness condition.

\section{Method}

\section{Participants and Experimental Design}

A total of 110 undergraduate students (34 males and 76 females, average age $M=$ 19.21 years, $S D=3.10$ ) at the University of Queensland were randomly assigned to the conditions of a 2 (prototypical vs. peripheral) x 2 (high vs. low group attractiveness) design.

\section{Procedure}

The procedure was the same as in Experiment 1, with two significant exceptions: (1) 
all participants were made accountable to their group members, and (2) group attractiveness was manipulated. Below we describe those aspects of the procedure that differed from the procedure used in Experiment 1.

Manipulation of group attractiveness. Upon arrival at the laboratory, participants completed a computerised "scrambled words test." The test consisted of sixty anagrams, each between 5 and 11 characters in length. Participants were instructed to solve as many anagrams as possible in a 4 minute period. In order to facilitate the provision of false feedback (see below), we included 10 unsolvable anagrams. After the presentation of the prototypicality manipulation (same as in Experiment 1) and the accountability instructions (all participants were told that their group members would monitor their negotiation behaviour), we provided bogus feedback on the anagram test, in the form of a Group Creativity Score. This score was described as "a weighted compound of the scores of you and your fellow group members, which reflects the group's creativity and is unrelated to the O/Ppersonality score."

This Group Creativity Score was used to manipulate group attractiveness. All participants were told that their Group Creativity Score was 92.5. Subsequently, participants in the low group attractiveness conditions learned that "the average creativity score of University of Queensland students is 138.4. Thus, your group scores below average on creativity, cognitive flexibility, and related cognitive skills." Participants in the high attractiveness conditions were told that "the average creativity score of University of Queensland students is 46.6. Thus, your group scores above average on creativity, cognitive flexibility, and related cognitive skills."

In order to be able to exclude the possibility that effects of the group attractiveness manipulation would be caused by unintended effects on mood or self-esteem, participants were asked to rate their current mood state on six 5-point scales (e.g., relaxed - nervous, self- 
assured - uncertain, happy - sad). Because of substantial intercorrelations, these items were combined in one index of participant's mood $(\alpha=.81)$. State self-esteem was measured with five items (e.g., "I feel inferior to others at this moment"; "I feel displeased with myself"), which were averaged into a self-esteem index $(\alpha=.92)$. Results revealed no effects of the manipulations on either of these scales, both $F s<1$, ns.

Dependent measures. As in Experiment 1, the key dependent variables were the number of cooperative and competitive messages sent, self-rated competitiveness, and average demands, which were measured in the same way as in Experiment 1 . The manipulation of group attractiveness was checked with five items: "How attractive do you find the P-group?" (1 = not very attractive, 9 = very attractive); "How proud are you to be a member of the P-group?" (1 = not very proud, 9 = very proud); "How glad are you to be a member of the P-group?" (1 = not so glad, 9 = very glad); "How much do you like the Pgroup" (1 = not very much, 9 = very much"); and "What is your general impression of the Pgroup?" (1 = very negative, 9 = very positive). These items were combined into an index of group attractiveness $(\alpha=.86)$. Compared to Experiment 1 , we used four additional items to check the successfulness of the prototypicality manipulation. The resulting prototypicality scale thus consisted of five items $(\alpha=.84)$ : "How central to the P-group do you feel you are?"; "How much do you feel you belong to the P-group?"; "How well do you feel you fit in the P-group?"; "Do you feel you are a good example of a P-group member?"; and "How similar do you feel to your fellow group members?"; "1 = not at all, 9 = a great deal). The accountability instructions were checked in the same way as in Experiment 1.

\section{Results}

\section{Treatment of the Data}

Data were analyzed by ANOVA over the full 2 (prototypical vs. peripheral) x 2 (attractive group vs. unattractive group) design. (Recall that all participants were given the 
accountability instructions.) Five participants reached agreement before the sixth negotiation round, and were excluded from further analyses due to missing values. As in Experiment 1, the numbers of competitive and cooperative messages were not independent $(r=-.44, p<$ .001), but results for both measures are reported for illustrative purposes.

\section{Manipulation Checks}

ANOVA revealed a significant main effect of prototypicality on the prototypicality index, $F(1,101)=45.80, p<.001, \eta^{2}=.31$--participants in the prototypical conditions felt more prototypical of their group than did those in the peripheral conditions $(M=5.70, S D=$ 1.23 vs. $M=3.89, S D=1.47)$. There were no other significant effects $(F s<1, n s)$. Further, participants in the high group attractiveness conditions judged the P-group as more attractive than did participants in the low attractiveness conditions $(M=6.94, S D=0.87$ vs. $M=4.80$, $S D=1.12), F(1,101)=119.35, p<.001, \eta^{2}=.54$ (there were no other effects, $F \mathrm{~s}<1, n s$ ). The accountability check was used to find out whether participants indeed felt accountable to their group members. A one-sample $t$ test revealed that the average response on the accountability check was significantly higher than the scale mean $(M=7.69, S D=1.44)$, $t(104)=19.16, p<.001$, indicating that the accountability instructions had been successful. Accountability ratings were not influenced by the other manipulations ( $F s<1, n s)$.

\section{Messages}

The numbers of cooperative and competitive messages were submitted to a 2 (prototypical vs. peripheral) x 2 (attractive vs. unattractive) x 2 (cooperative vs. competitive message) ANOVA with repeated measures on the third factor. This analysis yielded an interaction between prototypicality and message type, indicating that the relative amount of cooperative and competitive messages participants sent was influenced by prototypicality, $F(1,101)=7.55, p=.007, \eta^{2}=.07$. Below we report follow-up analyses to examine the specific patterns of cooperative and competitive messages across experimental conditions. 
Number of cooperative messages. We found a significant effect of prototypicality on the number of cooperative messages sent. As expected, peripheral group representatives sent fewer cooperative messages to the opponent than did prototypical representatives $(M=2.77$, $S D=1.86$ vs. $M=3.46, S D=1.70), F(1,101)=3.97, p=.049, \eta^{2}=.05$. Note that, because in Experiment 2 all participants were accountable to their group members, this constitutes a replication of the effect obtained in Experiment 1.

Number of competitive messages. Also consistent with Experiment 1, we obtained a significant main effect of prototypicality on the number of competitive messages sent: Peripheral group members sent more competitive messages than did prototypical group members $(M=1.94, S D=1.92$ vs. $M=1.10, S D=1.26), F(1,101)=7.08, p=.009, \eta^{2}=.07$.

Self-reported competitiveness. Self-reported competitiveness results were in line with the results described above. Consistent with the findings of Experiment 1, peripheral representatives reported more competitive intentions than did prototypical representatives ( $M$ $=4.95, S D=1.36$ vs. $M=4.05, S D=1.31), F(1,101)=12.00, p<.001, \eta^{2}=.11$.

\section{Demands}

We obtained a significant main effect of group attractiveness on average demands, showing that representatives of an attractive group made higher demands than did representatives of an unattractive group $(M=545, S D=82$ vs. $M=496, S D=80), F(1,101)$ $=9.88, p=.002, \eta^{2}=.09$. More important, we found a significant interaction between prototypicality and group attractiveness, $F(1,101)=4.39, p=.039, \eta^{2}=.05$ (see Figure 2). In support of Hypothesis 3, simple-effects analysis showed that peripheral representatives of an attractive group made higher demands than did prototypical representatives of an attractive group, $F(1,101)=4.01, p=.05, \eta^{2}=.07$. Peripheral and prototypical representatives of an unattractive group did not differ, $F(1,101)<1$, ns. 
The results of Experiment 2 support our hypotheses. Consistent with the findings of Experiment 1, peripheral representatives sent more competitive and fewer cooperative messages to the opponent than did prototypical representatives. (Recall that all participants in Experiment 2 were accountable.) Peripheral representatives also made tougher demands than did prototypical representatives, but only when the group was presented as attractive. When the group was presented as unattractive, prototypicality had no effect on representatives' demands. This pattern of results seems to suggest that, as anticipated, it takes a higher level of motivation to actually make competitive demands than it does to send competitive messages. We will return to this issue in more detail in the General Discussion section.

\section{General Discussion}

The present research investigated how a representative's behaviour in an intergroup negotiation is influenced by his or her standing within the group. Based on prior research (Hogg \& Abrams, 1988; Noel et al., 1995; Turner, 1985; Turner et al., 1987), it was predicted that peripheral group representatives, who occupy a marginal position within their group, would display tougher negotiation behaviour than prototypical group representatives, but only under conditions of process accountability. The results of Experiment 1 supported this prediction, by showing that peripheral representatives were more competitive in the level of their communications and self-rated behaviour than were prototypical representatives, but only when they believed that their group members were monitoring their behaviour.

Experiment 2 replicated and extended these findings. As in Experiment 1, peripheral representatives who were accountable to their group members sent more competitive and fewer cooperative messages to their opponent than did prototypical representatives. Furthermore, peripheral negotiators under accountability made tougher demands in the course of the negotiation than did prototypical negotiators, but only when their group was presented as attractive. When the group was presented as unattractive, prototypical and 
peripheral negotiators did not differ with respect to the toughness of their demands.

In exploring how a representative's position within the group influences his or her behaviour in intergroup negotiation, the present study brings together research on group member prototypicality and intergroup negotiation. The synthesis of these different lines of enquiry extends our knowledge about intergroup negotiation, the effects of prototypicality, and the role of impression management and strategic behaviour in intergroup relations. In the remainder of this paper, we consider some of the implications of our findings, discuss the strengths and weaknesses of our approach, and outline some avenues for future research.

\section{Implications and Contributions}

The present results have important implications for intergroup negotiation. Our findings suggest that representatives who are at the periphery of their group are motivated to convince their group members that they are really "one of us." When peripheral negotiators are under process accountability, expecting their fellow group members to monitor their negotiation behaviour, they behave more competitively toward the outgroup than do prototypical negotiators. However, when they are not accountable, expecting their behaviour to remain unknown to the other group members, they take a less competitive stance, behaving in much the same way as prototypical representatives.

Interestingly, the current results suggest that communicating competitive intentions and making competitive demands require different levels of motivation to be accepted as a group member. Under accountability, peripheral negotiators sent more competitive messages than did prototypical negotiators. However, they increased their actual demands only when group membership was made attractive. It would appear, then, that it takes a higher level of motivation to make competitive demands than it does to send competitive messages. As alluded to earlier, communicating competitive intentions is a relatively safe way of conveying a tough impression to one's constituents (Wall, 1991). By contrast, making high 
demands is a risky venture, which is likely to cause impasse and leave the group emptyhanded (Pruitt, 1981). A tentative conclusion that follows from these results is that individuals are only motivated to take such a risk when group membership is perceived as highly desirable. This conclusion is in line with Jetten et al.'s (2005) assertion that peripherals are more sensitive to social context and are more likely to make a cost-benefit analysis when determining whether or not to engage in group-favouring behaviour. It would appear that peripherals are more likely to follow the more risky strategy of making intransigent demands to the extent that the potential benefits of such a strategy increase (e.g., when doing so increases acceptance by the members of a highly attractive group). However, it should be noted that this assumption was not directly tested in the present study.

The present research provides additional--albeit indirect--evidence concerning the reasons why peripheral group members are motivated to make a favourable impression on their group members. It seems likely that the behaviour of peripheral members in intergroup negotiation is fueled by strategic considerations aimed at increasing acceptance by the other group members. Although we have no direct evidence supporting a mediating role of such strategic motivation, we believe it is a good candidate for three reasons. First, peripherals sent more competitive messages to the outgroup only when their fellow group members could monitor their behaviour, which may be interpreted as an indication of strategic motives. After all, it is much easier to impress one's group members and enhance one's position within the group by displaying tough behaviour when those group members take notice of one's behaviour. Second, peripheral group members who were held accountable for their negotiation behaviour made more competitive demands only when they perceived group membership as attractive. This too suggests that strategic considerations (i.e., a cost-benefit analysis) determine whether peripherals will show tough behaviour toward the outgroup. Third, recent research by Jetten and colleagues (Jetten et al., 2003, 2005, in press) also 
suggests that peripherals are more strategic in their decisions regarding whether or not to exert themselves on behalf of the group than are prototypicals. Whereas prototypicals in general are likely to expend effort on behalf of the group, peripherals appear to be more likely to work for the group to the extent that doing so entails strategic advantages (e.g., increased acceptance by other group members).

These findings shed new light on the role of impression management in intergroup negotiation. Rahim and Buntzman (1991) noted that impression management plays an important role in conflict situations, and they deplored the fact that very little research had addressed the issue. The present research adds to our understanding of the role of impression management in conflict situations. It illustrates that under specific circumstances, the competitive behaviour of negotiators in intergroup disputes may not be aimed at furthering the group's interests, but rather at improving their own position within the group. It further appears that prototypical group representatives are quite consistent in their behaviour regardless of whether or not they perceive the group as attractive. In contrast, peripheral group representatives, whose status within the group is less secure, appear to be much more sensitive to situational changes. In the present studies, peripheral representatives adopted a competitive strategy in their negotiation with the outgroup representative only when they believed that their fellow group members could monitor their behaviour and group membership was made attractive. This suggests that peripheral group members' behaviour is highly strategic and aimed at making a favourable impression on the ingroup, rather than on defending the group's interests per se. This conclusion is in line with research by Barreto and Ellemers (2000), who found that high identifiers displayed pro-group behaviour regardless of whether they were accountable to their group members, whereas low identifiers displayed pro-group behaviour when they were accountable and individualistic behaviour when they were anonymous. 
The present analysis of representative behaviour in intergroup negotiation is inspired by the social identity approach, and specifically by the notion of prototypicality as described in self-categorization theory (Turner, 1985; Turner et al., 1987). It is important to note, however, that our adoption of this perspective does not deny that other analyses of group processes might arrive at similar predictions. For example, in their investigation of the role of leadership stability in intergroup conflict, Rabbie and Bekkers (1978) started from the commonsensical idea that leaders of nations who feel threatened will be likely to engage in intergroup conflict in an attempt to unify the nation behind them and/or divert the public's attention from their precarious position. Interestingly, however, although these authors do not explicitly base their predictions on a social identity analysis, they do assume that "unstable leaders are likely to choose intergroup competition, since they are motivated to prove themselves in an attempt to assure their chances for re-election," an argument that is strongly compatible with our analysis. We decided to adopt self-categorization theory as our main perspective because it provides a comprehensive analysis of intergroup behaviour. However, we do not claim that this analysis of intergroup negotiation is the only viable one.

\section{Limitations and Directions for Future Research}

A key feature of self-categorization theory is that not only which group memberships are self-definitionally salient but also the way in which we actually represent the groups, the prototypes themselves, are influenced by the social context (e.g., Turner et al., 1987). There is some debate among social identity scholars on the degree of malleability of group prototypes. Some argue that group prototypes are relatively dramatically responsive to immediate features of transitory situations (e.g., Oakes, Haslam, \& Turner, 1998). Others argue that group prototypes anchor and lend stability to our representations of the social world and so although they are responsive to context they also have a degree of inertia (e.g., Abrams \& Hogg, 2001; Hogg, 2003). This analysis is consistent with uncertainty reduction 
theory that focuses on the self-conceptual uncertainty reduction function of group prototypes (e.g., Hogg, 2000), and with research showing how difficult it is to change group stereotypes (e.g., Hilton \& von Hippel, 1996; Leyens, Yzerbyt, \& Schadron, 1994; Tajfel, 1981). Since the aim of the present study was not to demonstrate fluctuations in individuals' prototypicality as a function of the situation but rather to explore the effects of prototypicality in intergroup negotiation we decided to model our operationalisation of prototypicality on a more fixed representation of prototypes.

We found that peripheral group representatives (as compared to prototypical ones) behaved more competitively toward the outgroup, but only when they were accountable to their group members and group membership was made attractive. On the basis of these findings and previous work by Jetten et al. (2003, 2005, in press) we tentatively concluded that peripheral group members' behaviour is fueled by strategic considerations aimed at increasing acceptance by their fellow group members. When group membership is made attractive and the likelihood of acceptance by the other group members can possibly be influenced (e.g., when the other group members monitor the peripheral representative's negotiation behaviour), peripheral representatives adopt a more competitive stance vis-à-vis the outgroup than when group membership is unattractive and/or the likelihood of acceptance cannot be influenced through negotiation behaviour. Although these findings are suggestive of strategic motives, it is important to note that we have no direct measures of such motives. Future research is needed to gain more insight into the role of strategic considerations as predictors of peripheral group members' behaviour in intergroup settings.

\section{Conclusion}

In their discussion of intergroup negotiation, Pruitt and Carnevale (1993, p. 153) state that "when groups and organizations face each other in negotiation, within-group dynamics can have important consequences for the between-group negotiation." Despite the obvious 
importance of this claim, few studies have systematically investigated the impact of such within-group dynamics in an intergroup context. Extending the sparse extant research, the current work demonstrates that, under specific conditions, a representative's standing within the group may have a significant impact on his or her behaviour in intergroup negotiation. Specifically, we found that peripheral group representatives (as opposed to prototypical ones) behaved more competitively toward the outgroup when they were held accountable by their fellow group members and group membership was perceived as attractive. Organizations and nations in conflict may want to keep this in mind when selecting a group member to represent them in negotiations with the outgroup. 


\section{References}

Abrams, D., \& Hogg, M. A. (2001). Collective identity: Group membership and selfconception. In M. A. Hogg \& R. S. Tindale (Eds.), Blackwell handbook of social psychology: Group processes (pp. 425-460). Oxford, UK: Blackwell.

Adams, J. S. (1976). The structure and dynamics of behaviour in organizational boundary roles. In M. D. Dunnette (Ed.), Handbook of industrial and organizational psychology (pp. 1175-1199). Chicago: Rand McNally.

Adelberg, S., \& Batson, C. D. (1978). Accountability and helping: When needs exceed resources. Journal of Personality and Social Psychology, 36, 342-350

Barreto, M., \& Ellemers, N. (2000). You can't always do what you want: Social identity and self-presentational determinants of the choice to work for a low-status group. Personality and Social Psychology Bulletin, 26, 891-906.

Baumeister, R. F., \& Leary, M. R. (1995). The need to belong: Desire for interpersonal attachments as a fundamental human motivation. Psychological Bulletin, 117, 497529.

Benton, A. A. (1972). Accountability and negotiations between group representatives. Proceedings of the Eightieth Annual Conference of the American Psychological Association (pp. 227-228).

Benton, A. A., \& Druckman, D. (1974). Constituent's bargaining orientation and intergroup negotiations. Journal of Applied Social Psychology, 4, 141-150.

Ben-Yoav, O., \& Pruitt, D. G. (1984). Accountability to constituents: A two-edged sword. Organizational Behaviour and Human Decision Processes, 34, 283-295.

Branscombe, N. R., Wann, D. L., Noel, J. G., \& Coleman, J. (1993). Ingroup or outgroup extremity: Importance of threatened social identity. Personality and Social Psychology Bulletin, 19, 381-388. 
Breaugh, J. A., \& Klimoski, R. J. (1977). The choice of a group spokesman in bargaining: Member or outsider? Organizational Behaviour and Human Decision Processes, 19, 325-336.

Brewer, M. B., \& Kramer, R. M. (1986). Choice behaviour in social dilemmas: Effects of social identity, group size, and decision framing. Journal of Personality and Social Psychology, 50, 543-549.

Carnevale, P. J., Pruitt, D. G., \& Britton, S. D. (1979). Looking tough: The negotiator under constituent surveillance. Personality and Social Psychology Bulletin, 5, 118-121.

Carnevale, P. J., Pruitt, D. G., \& Seilheimer, S. D. (1981). Looking and competing: Accountability and visual access in integrative bargaining. Journal of Personality and Social Psychology, 40, 111-120.

Couch, C. J. (1986). Structural conditions of intergroup negotiations. In C. J. Couch, S. L. Saxton, \& M. A. Katovich (Eds.), Studies in symbolic interaction: A research annual (pp. 353-364). Stamford, CT: JAI Press.

De Cremer, D. (2002). Respect and cooperation in social dilemmas: The importance of feeling included. Personality and Social Psychology Bulletin, 28, 1335-1341.

De Dreu, C. K. W. (1995). Coercive power and concession making in bilateral negotiation. Journal of Conflict Resolution, 39, 646-670.

De Dreu, C. K. W., Carnevale, P. J., Emans, B. J. M., \& Van De Vliert, E. (1994). Effects of gain-loss frames in negotiation: Loss aversion, mismatching, and frame adoption. Organizational Behaviour and Human Decision Processes, 60, 90-107.

De Dreu, C. K. W., \& Van Kleef, G. A. (2004). The influence of power on the information search, impression formation, and demands in negotiation. Journal of Experimental Social Psychology, 40, 303-319.

De Dreu, C. K. W., \& Van Lange, P. A. M. (1995). The impact of social value orientations 
on negotiator cognition and behaviour. Personality and Social Psychology Bulletin, $21,1178-1188$.

Druckman, D. (1994). Determinants of compromising behaviour in negotiation: A metaanalysis. Journal of Conflict Resolution, 38, 507-556.

Druckman, D., Solomon, D., \& Zechmeister, K. (1972). Effects of representative role obligations on the process of children's distribution of resources. Sociometry, 35, 489501.

Ellemers, N., Spears, R., \& Doosje, B. (2002). Self and social identity. Annual Review of Psychology, 53, 161-186.

Fielding, K. S., \& Hogg, M. A. (1997). Social identity, self-categorization, and leadership: A field study of small interactive groups. Group Dynamics, 1, 39-51.

Frey, R. L., \& Adams, J. S. (1972). The negotiator's dilemma: Simultaneous in-group and out-group conflict. Journal of Experimental Social Psychology, 8, 331-346.

Gelfand, M. J., \& Realo, A. (1999). Individualism-collectivism and accountability in intergroup negotiations. Journal of Applied Psychology, 84, 721-736.

Gruder, C. L. (1971). Relationship with opponent and partner in mixed-motive bargaining. Journal of Conflict Resolution, 15, 403-416.

Gruder, C. L., \& Rosen, N. (1971). Effects of intergroup relations on intergroup bargaining. International Journal of Group Tensions, 1, 301-317.

Haccoun, R., \& Klimoski, R. J. (1975). Negotiator status and accountability source: A study of negotiator behaviour. Organizational Behaviour and Human Decision Processes, 14, 342-359.

Hains, S. C., Hogg, M. A., \& Duck, J. M. (1997). Self-categorization and leadership: Effects of group prototypicality and leader stereotypicality. Personality and Social Psychology Bulletin, 23, 1087-1099. 
Hermann, M. G., \& Kogan, N. (1968). Negotiation in leader and delegate groups. Journal of Conflict Resolution, 12, 332-344.

Hilton, J. L., \& von Hippel, W. (1996). Stereotypes. Annual Review of Psychology, 47, 237271.

Hilty, J. A., \& Carnevale, P. J. (1993). Black-hat/white-hat strategy in bilateral negotiation. Organizational Behaviour and Human Decision Processes, 55, 444-469.

Hogg, M. A. (1993). Group cohesiveness: A critical review and some new directions. European Review of Social Psychology, 4, 85-111.

Hogg, M. A. (2000). Subjective uncertainty reduction through self-categorization: A motivational theory of social identity processes. European Review of Social Psychology, 11, 223-255.

Hogg, M. A. (2001). A social identity theory of leadership. Personality and Social Psychology Review, 5, 184-200.

Hogg, M. A. (2003). Social identity. In M. R. Leary \& J. P. Tangney (Eds.), Handbook of self and identity (pp. 462-479). New York: Guilford.

Hogg, M. A. (2005). All animals are equal but some animals are more equal than others: Social identity and marginal membership. In K. D. Williams, J. P. Forgas, \& W. von Hippel (Eds.), The social outcast: Ostracism, social exclusion, rejection, and bullying (pp. 243-261). New York: Psychology Press.

Hogg, M. A., \& Abrams, D. A. (1988). Social identifications: A social psychology of intergroup relations and group processes. London: Routledge, Chapman \& Hall.

Hogg, M. A., Hains, S. C., \& Mason, I. (1998). Identification and leadership in small groups: Salience, frame of reference, and leader stereotypicality effects on leader evaluations. Journal of Personality and Social Psychology, 75, 1248-1263.

Hogg, M. A., \& van Knippenberg, D. (2003). Social identity and leadership processes in 
groups. In M. P. Zanna (Ed.), Advances in experimental social psychology (Vol. 35, pp. 1-52). San Diego, CA: Academic Press.

Insko, C. A., Schopler, J., Hoyle, R. H., Dardis, G. J., \& Graetz, K. A. (1990). Individualgroup discontinuity as a function of fear and greed. Journal of Personality and Social Psychology, 58, 68-79.

Jetten, J., Branscombe, N. R., \& Spears, R. (2002). On being peripheral: Effects of insecurity on personal and collective self-esteem. European Journal of Social Psychology, 32, 105-123.

Jetten, J., Branscombe, N. R., Spears, R., \& McKimmie, B. M. (2003). Predicting the paths of peripherals: The interaction of identification and future possibilities. Personality and Social Psychology Bulletin, 29, 130-140.

Jetten, J., Hornsey, M. J., \& Adarves-Yorno, I. (in press). When group members admit to being conformist: The role of relative intragroup status in conformity self-reports. Personality and Social Psychology Bulletin.

Jetten, J., Hornsey, M. J., Spears, R., Haslam, S. A., \& Cowell, E. (2005). Keeping up appearances: The conditional nature of peripheral group members' loyalty expressions and actions. Manuscript submitted for publication.

Jetten, J., Spears, R., \& Manstead, A. S. R. (1997). Distinctiveness threat and prototypicality: Combined effects on intergroup discrimination and collective self-esteem. European Journal of Social Psychology, 27, 635-657.

Jones, E. E., \& Pittman, T. S. (1982). Toward a general theory of strategic self-presentation. In J. Suls (Ed.), Psychological perspectives on the self (Vol. 1, pp. 231-262). Hillsdale, NJ: Erlbaum.

Klimoski, R. J. (1972). The effect of intragroup forces on intergroup conflict resolution. Organizational Behaviour and Human Decision Processes, 8, 363-383. 
Klimoski, R. J., \& Ash, R. A. (1974). Accountability and negotiation behaviour. Organizational Behaviour and Human Decision Processes, 11, 409-425.

Kogan, N., Lamm, H., \& Trommsdorff, G. (1972). Negotiation constraints in the risk-taking domain: Effects of being observed by partners of higher or lower status. Journal of Personality and Social Psychology, 23, 143-156.

Komorita, S. S, \& Lapworth, C. W. (1982). Cooperative choice among individuals versus groups in an $n$-person dilemma situation. Journal of Personality and Social Psychology, 42, 487-496.

Kramer, R. M. (1991a). Intergroup relations and organizational dilemmas: The role of categorization processes. In L. L. Cummings \& B. M. Staw (Eds.), Research in organizational behaviour (Vol. 13, pp. 191-228). Greenwich, CT: JAI Press.

Kramer, R. M. (1991b). The more the merrier? Social psychological aspects of multiparty negotiations in organizations. Research on Negotiation in Organizations, 3, 307-332.

Leyens, J.-P., Yzerbyt, V., \& Schadron, G. (1994). Stereotypes and social cognition. London: Sage.

Lindskold, S., McElwain, D. C., \& Wayner, M. (1977). Cooperation and the use of coercion by groups and by individuals. Journal of Conflict Resolution, 21, 531-550.

Moreland, R. L. (1985). Social categorization and the assimilation of "new" group members. Journal of Personality and Social Psychology, 48, 1173-1190.

Moreland, R. L., \& Levine, J. M. (1989). Newcomers and oldtimers in small groups. In P. B. Paulus (Ed.), Psychology of group influence (2nd ed., pp. 143-186). Hillsdale, NJ, England: Lawrence Erlbaum.

Noel, J. G., Wann, D. L., \& Branscombe, N. R. (1995). Peripheral ingroup membership status and public negativity toward outgroups. Journal of Personality and Social Psychology, 68, 127-137. 
Oakes, P., Haslam, A., \& Turner, J. C. (1998). The role of prototypicality in group influence and cohesion: Contextual variation in the graded structure of social categories. In S. Worchel, J. F. Morales, D. Páez, \& J.-C. Deschamps (Eds.), Social identity: International perspectives (pp. 75-92). London: Sage.

Platow, M. J., \& van Knippenberg, D. (2001). A social identity analysis of leadership endorsement: The effects of leader ingroup prototypicality and distributive intergroup fairness. Personality and Social Psychology Bulletin, 27, 1508-1519.

Pruitt, D. G. (1981). Negotiation behaviour. New York: Academic Press.

Pruitt, D. G., \& Carnevale, P. J. (1993). Negotiation in social conflict. Buckingham, UK: Open University Press.

Putnam, L. L., \& Poole, M. S. (1987). Conflict and negotiation. In F. M. Jablin, L. L. Putnam, K. H. Roberts, \& L. W. Porter (Eds.), Handbook of organizational communication: An interdisciplinary perspective (pp. 549-599). Thousand Oaks, CA: Sage.

Rahim, M. A., \& Buntzman, G. F. (1991). Impression management and organizational conflict. In R. A. Giacalone \& P. Rosenfeld (Eds.), Applied impression management: How image making affects managerial decisions (pp. 157-174). Thousand Oaks, CA: Sage.

Rothbart, M., \& Hallmark, W. (1988). Ingroup-outgroup differences in the perceived efficacy of coercion and conciliation in resolving social conflict. Journal of Personality and Social Psychology, 55, 248-257.

Rubin, J. Z., \& Sander, E. A. F. (1988). When should we use agents? Direct versus representative negotiation. Negotiation Journal, 4, 395-401.

Schmitt, M. T., \& Branscombe, N. R. (2001). The good, the bad, and the manly: Threats to one's prototypicality and evaluations of fellow in-group members. Journal of 
Experimental Social Psychology, 37, 510-517.

Schopler, J., Insko, C. A., Graetz, K. A., Drigotas, S. M., \& Smith, V. A. (1991). The generality of the individual-group discontinuity effect: Variations in positivitynegativity of outcomes, players' relative power, and magnitude of outcomes. Personality and Social Psychology Bulletin, 17, 612-624.

Stephenson, G. M. (1981). Intergroup bargaining and negotiation. In J. C. Turner \& H. Giles (Eds.), Intergroup behaviour (pp. 168-198). Oxford, UK: Blackwell.

Tajfel, H. (1981). Social stereotypes and social groups. In J. C. Turner \& H. Giles (Eds.), Intergroup behaviour (pp. 144-167). Oxford, UK: Blackwell.

Tajfel, H., \& Turner, J. C. (1986). The social identity theory of intergroup behaviour. In S. Worchel \& W. Austin (Eds.), The social psychology of intergroup relations (pp. 724). Chicago: Nelson-Hall.

Thompson, L., \& Hrebec, D. (1996). Lose-lose agreements in interdependent decision making. Psychological Bulletin, 120, 396-409.

Turner, J. C. (1985). Social categorization and the self-concept: A social cognitive theory of group behaviour. In E. J. Lawler (Ed.), Advances in group processes: Theory and research (Vol. 2, pp. 77-121). Greenwich, CT: JAI Press.

Turner, J. C., Hogg, M. A., Oakes, P. J., Reicher, S. D., \& Wetherell, M. S. (1987). Rediscovering the social group: A self-categorization theory. Cambridge, MA: Basil Blackwell.

Van Kleef, G. A., De Dreu. C. K. W., \& Manstead, A. S. R. (2004a). The interpersonal effects of anger and happiness in negotiation. Journal of Personality and Social Psychology, 86, 57-76.

Van Kleef, G. A., De Dreu, C. K. W., \& Manstead, A. S. R. (2004b). The interpersonal effects of emotions in negotiations: A motivated information processing approach. 
Journal of Personality and Social Psychology, 87, 510-528.

van Knippenberg, D., \& Hogg, M. A. (2003). A social identity model of leadership effectiveness in organizations. In R. M. Kramer \& B. M. Staw (Eds.), Research in organizational behaviour (Vol. 25, pp. 245-297). Amsterdam: Elsevier.

van Knippenberg, D., Lossie, N., \& Wilke, H. (1994). In-group prototypicality and persuasion: Determinants of heuristic and systematic message processing. British Journal of Social Psychology, 33, 289-300.

van Knippenberg, D., van Knippenberg, B., \& Van Dijk, E. (2000). Who takes the lead in risky decision making? Effects of group members' risk preferences and prototypicality. Organizational Behaviour and Human Decision Processes, 83, 213234.

Wall, J. A., Jr. (1975). Effects of constituents' trust and representative bargaining orientation on intergroup bargaining. Journal of Personality and Social Psychology, 31, 10041012.

Wall, J. A., Jr. (1991). Impression management in negotiations. In R. A. Giacalone \& P. Rosenfeld (Eds.), Applied impression management: How image-making affects managerial decisions (pp. 133-156). Thousand Oaks, CA: Sage.

Walton, R. E., \& McKersie, R. B. (1965). A behavioural theory of labor negotiations. New York: McGraw-Hill. 


\section{Footnote}

${ }^{1}$ A pilot study showed that different distributions of prototypical and peripheral group members (i.e., a 3-1 vs. a 2-2 distribution) did not influence the effects of prototypicality. 
Table 1

Participants' Payoff Chart (Experiments 1 and 2)

\begin{tabular}{|c|c|c|c|c|c|}
\hline \multicolumn{2}{|c|}{ Amaro Campaign } & \multicolumn{2}{|c|}{ Bailo Campaign } & \multicolumn{2}{|c|}{ Cogo Campaign } \\
\hline Level & Reward P-group & Level & Reward P-group & Level & Reward P-group \\
\hline 1 & 400 & 1 & 120 & 1 & 240 \\
\hline 2 & 350 & 2 & 105 & 2 & 210 \\
\hline 3 & 300 & 3 & 90 & 3 & 180 \\
\hline 4 & 250 & 4 & 75 & 4 & 150 \\
\hline 5 & 200 & 5 & 60 & 5 & 120 \\
\hline 6 & 150 & 6 & 45 & 6 & 90 \\
\hline 7 & 100 & 7 & 30 & 7 & 60 \\
\hline 8 & 50 & 8 & 15 & 8 & 30 \\
\hline 9 & 0 & 9 & 0 & 9 & 0 \\
\hline
\end{tabular}


Table 2

Number of Cooperative and Competitive Messages Sent and Self-Rated Competitiveness as a Function of Ingroup Prototypicality and Process Accountability in Experiment 1

Prototypical Peripheral

\# Cooperative Messages

Accountable

Non-Accountable

Non-Accountable

Non-Accountable
Accountable

$3.27 \mathrm{~b}$

$2.68_{\mathrm{ab}}$

(1.74)

\# Competitive Messages

Accountable

$1.20_{\mathrm{a}}$

$1.86_{\mathrm{ab}}$

Self-Rated Competitiveness

$4.32 \mathrm{~b}$

$4.96_{\mathrm{ab}}$

(1.18)
$5.34 a$

$2.21_{\mathrm{a}}$

$3.22_{b}$

$2.46_{b}$

$1.63_{a}$

$4.53_{b}$

Note. Means within a section not sharing a subscript differ at $p<.05$. Standard deviations are presented between brackets. 


\section{Figure Caption}

Figure 1. Graphical Representation of the O/P Continuum (used in Experiments 1 and 2).

Figure 2. Demand Level as a Function of Ingroup Prototypicality and Group Attractiveness in Experiment 2. Note. All participants in Experiment 2 were process accountable. Average demands are plotted in the graph. Standard deviations ranged from 75 to 84 . 


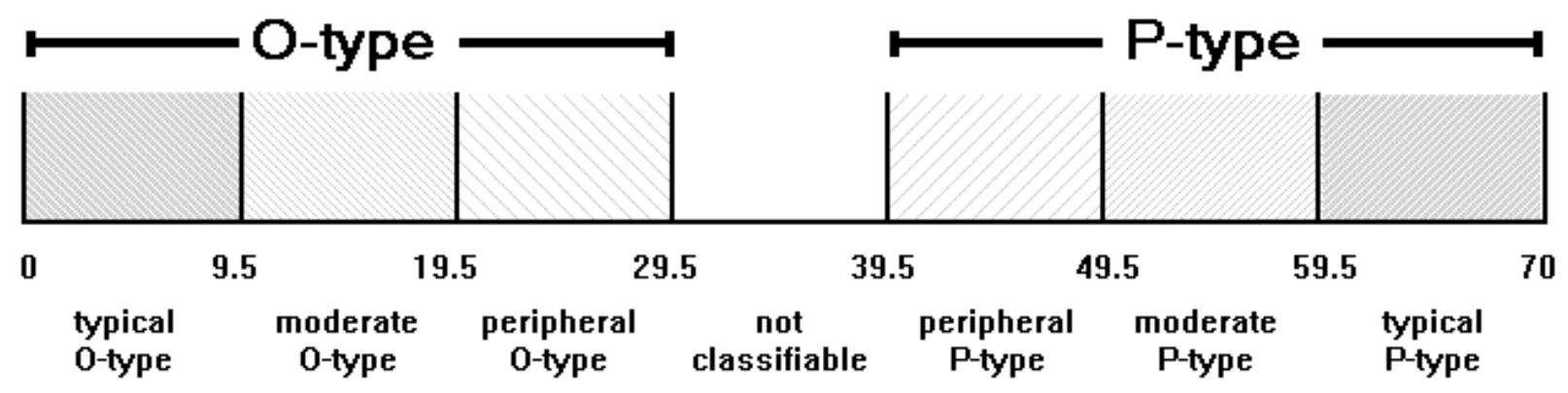




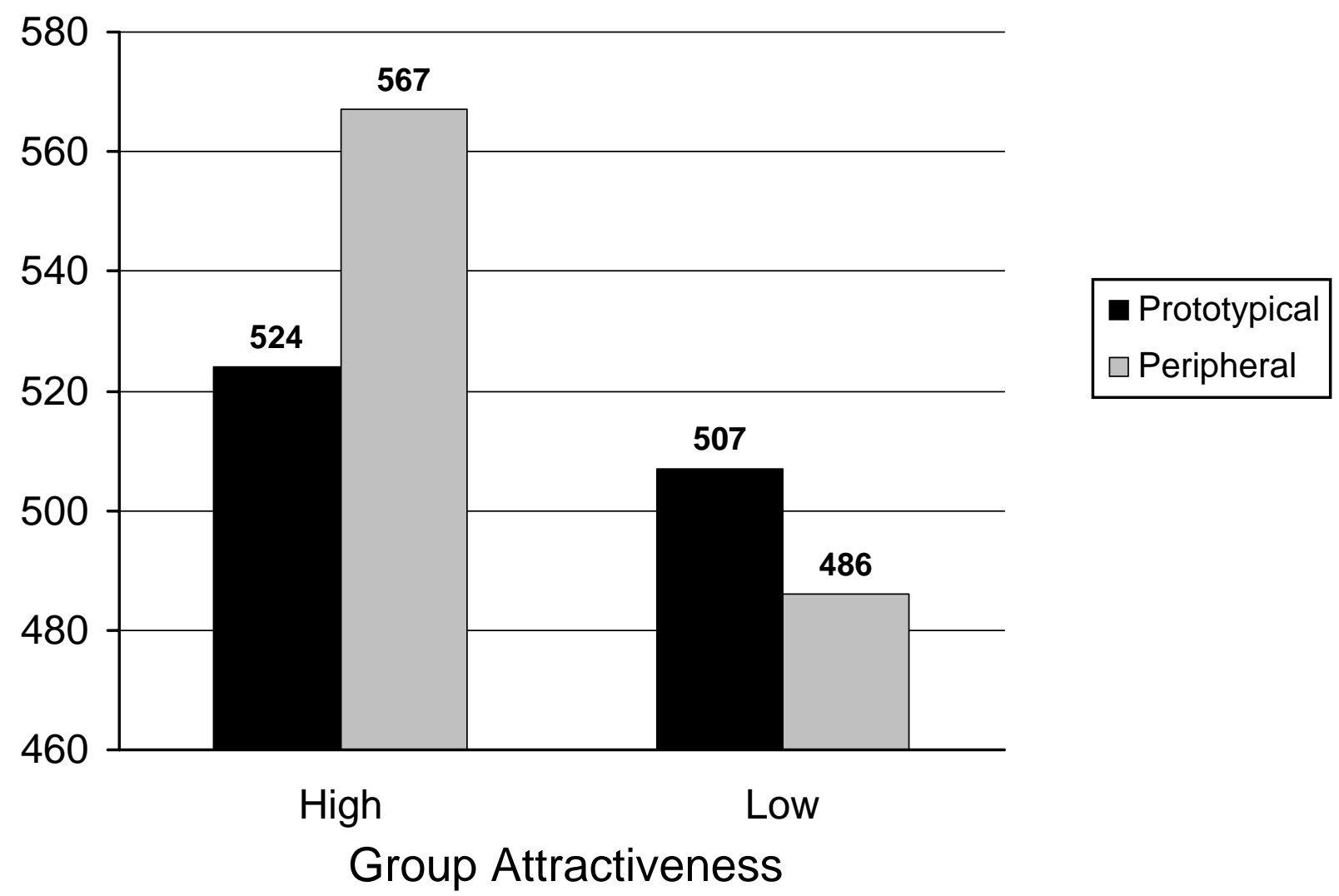




\section{Publications in the ERIM Report Series Research* in Management}

\section{ERIM Research Program: "Organizing for Performance"}

\section{6}

IPRs, Technological Development, and Economic Development

Wilfred Dolfsma

ERS-2006-004-ORG

http://hdl.handle.net/1765/7301

Institution Building and Change in China

Barbara Krug and Hans Hendrischke

ERS-2006-008-ORG

http://hdl.handle.net/1765/7331

Rational Entrepreneurship in Local China: Exit Plus Voice for Preferential Tax Treatments

Ze Zhu, George W.J. Hendrikse and Barbara Krug

ERS-2006-010-ORG

http://hdl.handle.net/1765/7577

A Process Model of Locational Change in Entrepreneurial Firms: An Evolutionary Perspective Erik Stam

ERS-2006-014-ORG

http://hdl.handle.net/1765/7633

Starting Anew: Entrepreneurial Intentions and Realizations Subsequent to Business Closure Veronique Schutjens and Erik Stam

ERS-2006-015-ORG

$\underline{\text { http://hdl.handle.net/1765/7638 }}$

Agglomeration Economies and Entrepreneurship in the ICT Industry

Frank G. van Oort and Erik Stam

ERS-2006-016-ORG

http://hdl.handle.net/1765/7639

Renascent Entrepreneurship

Erik Stam, David Audretsch and Joris Meijaard

ERS-2006-017-ORG

http://hdl.handle.net/1765/7640

Social Life of Values

Slawomir Magala

ERS-2006-019-ORG

http://hdl.handle.net/1765/7645

Enterprise Ground Zero in China

ERS-2006-024-ORG

Barbara Krug

$\underline{\text { http://hdl.handle.net/1765/7853 }}$

Framing China: Transformation and Institutional Change

ERS-2006-025-ORG

Barbara Krug and Hans Hendrischke

http://hdl.handle.net/1765/7854 
Currents and Sub-currents in the River of Innovations - Explaining Innovativeness using New-Product Announcements Wilfred Dolfsma and Gerben van der Panne

ERS-2006-036-ORG

http://hdl.handle.net/1765/7943

Much Ado About Nothing: A conceptual critique of CSR

J. (Hans) van Oosterhout and Pursey P. M. A. R. Heugens

ERS-2006-040-ORG

http://hdl.handle.net/1765/7894

The Effect of Business Regulations on Nascent and Young Business Entrepreneurship

André van Stel, David J. Storey and A. Roy Thurik

ERS-2006-052-ORG

http://hdl.handle.net/1765/7996

Postmaterialism Influencing Total Entrepreneurial Activity across Nations

Lorraine Uhlaner and A. Roy Thurik

ERS-2006-062-ORG

http://hdl.handle.net/1765/8128

The Lag Structure of the Impact of Business Ownership on Economic Performance in OECD Countries

Martin Carree and A. Roy Thurik

ERS-2006-064-ORG

http://hdl.handle.net/1765/8126

Uncertainty Avoidance and the Rate of Business Ownership Across 21 OECD Countries, 1976-2004

Sander Wennekers, A. Roy Thurik, André van Stel and Niels Noorderhaven

ERS-2006-065-ORG

http://hdl.handle.net/1765/8125

Interacting Dimensions of Diversity: Cross-Categorization and the Functioning of Diverse Work Groups Astrid C. Homan, Daan van Knippenberg, Gerben A. Van Kleef and Carsten K. W. De Dreu ERS-2006-069-ORG

Group Member Prototypicality and Intergroup Negotiation: How One's Standing in the Group Affects Negotiation Behaviour Gerben A. Van Kleef, Wolfgang Steinel, Daan van Knippenberg, Michael A. Hogg and Alicia Svensson ERS-2006-070-ORG

Bridging Faultlines by Valuing Diversity: Diversity Beliefs, Information Elaboration, and Performance in Diverse Work Groups Astrid C. Homan, Daan van Knippenberg, Gerben A. Van Kleef and Carsten K. W. De Dreu ERS-2006-071-ORG

Affective Match: Leader Emotional Displays, Follower Positive Affect, and Follower Performance Frederic Damen, Barbara van Knippenberg and Daan van Knippenberg ERS-2006-072-ORG

Leadership and Fairness: The State of the Art

Daan van Knippenberg, David De Cremer and Barbara van Knippenberg

ERS-2006-073-ORG 
* A complete overview of the ERIM Report Series Research in Management: https://ep.eur.nl/handle/1765/1

ERIM Research Programs:

LIS Business Processes, Logistics and Information Systems ORG Organizing for Performance

MKT Marketing

F\&A Finance and Accounting

STR Strategy and Entrepreneurship 